\title{
EVALUASI PENANGANAN IRADIASI BATU TOPAZ PADA OPERASI REAKTOR SIKLUS 94 DAN 95
}

\section{EVALUATION TOPAZ IRRADIATION HANDLING ON CORE OF 94 \& 95 OPERATING REACTORS}

\author{
Pardi, Banyu RF \\ 1,2PRSG-BATAN Kawasan Puspiptek Gd. 30 Serpong, 15310 \\ E-mail: pardi@batan.go.id
}

Diterima: 4 Mei 2018, diperbaiki : 23 Mei 2018, disetujui : 24 Mei 2018

\begin{abstract}
ABSTRAK
EVALUASI PENANGANAN IRADIASI BATU TOPAZ PADA OPERASI REAKTOR SIKLUS 94 DAN 95. Untuk memaksimalkan penggunaan reaktor RSG-GAS dalam memenuhi kepentingan pihak pengguna antara lain adalah melayani iradiasi target batu topaz saat reaktor operasi. Keandalan operasi reaktor perlu dijaga dan tingkatkan tanpa mengurangi faktor keselamatannya, salah satu keandalan operasi reaktor adalah kemampuan batang kendali pengatur (reg-rod) dalam mengimbangi perubahan reaktivitas di teras reaktor akibat gangguan dari pemasukan/penarikan target iradiasi. Reaktivitas, kecepatan, panjang langkah batang kendali pengatur (reg-rod) dan reaktivitas maksimum pada satu posisi iradiasi $<0,5 \%$ ditentukan dalam LAK, untuk penanganan iradiasi target batu topaz nilai reaktivitas sebesar $\pm 0,0741 \%$ diperlukan kehati-hatian dengan membuat gerakan pemasukan/penarikan target sambil melihat kanal pemantau daya dan display daya digital. Pada makalah ini dilakukan evaluasi kegiatan penanganan target iradiasi batu topaz pada siklus operasi 94 dan 95, dengan menganalisis data kegiatan yang tercatat dalam buku induk operasi dan formulir iradiasi target batu topaz. Hasil evaluasi pada siklus operasi 94: iradiasi target topaz total sebanyak $=360 \mathrm{kali}$ dengan massa total $324 \mathrm{~kg}$ dan pada siklus operasi 95: sebanyak = 576 kali dengan massa total $864 \mathrm{~kg}$. Dalam melakukan radiasi target topaz tidak terjadi gangguan karena telah dilakukan analisis keselamatan terlebih dahulu serta pelaksanaan yang sesuai dengan SOP sehingga tidak mempengaruhi reaktivitas di teras begitu pula keselamatan radiasi untuk personil harus di jaga.
\end{abstract}

Kata kunci : evaluasi, penanganan target iradiasi batu topaz.

\section{ABSTRACT}

EVALUATION TOPAZ IRRADIATION HANDLING ON CORE OF 94 \& 95 OPERATING REACTORS. The one of maximaze reactors RSG-GAS utilization to serve customer requirement is service irradiation topaz gamstone. Reliability of operating reactors have to guarded and without decrease safety factor, and one of Reliability of operating reactors is ability regulation control rod (reg-rod) to compensate changes in reactivity outcome enter/eject iradiation sample. Reactivity, rod speed, step lenght regulation control rod (reg-rod) and maximum reactivity at one radiation position $<0,5 \%$ is lised in LAK. When handling topaz iradiation, reactivity value is $\pm 0,0741 \%$, is needed slow motion enter/eject target while looking measurement power channels and also digital power display. In this paper to evaluate topaz handling activities on the core of 94 \& 95 operating reactors, by analyzing of data activities from book master operation and topaz irradiation target form. The evaluation result on core of operation 94 :irradiation topaz as much 360 times with total weigth $324 \mathrm{~kg}$ and on core of operation 95 : irradiation topaz as much 576 times total weigth $864 \mathrm{~kg}$. Irradiation of topaz 
stones have no interruption because have been safety evaluated and also implementation in accordance with SOP so as very influential in reactor core, so as radiation safety personel have to guarded.

Keywords: Evaluation, topaz handling activities on the core

\section{PENDAHULUAN}

R eaktor RSG - GAS merupakan fasilitas penyedia sumber neutron dengan fluks neutron rerata $2 \times$ $10^{14} \mathrm{n} / \mathrm{cm}^{2} \mathrm{~s}$. Sebagai fasilitas penyedia sumber neutron, pengoperasian reaktor dapat dimanfaatkan oleh pihak pengguna untuk kegiatan utilisasi dengan tujuan untuk penelitian dan produksi radioisotop diantaranya pewarnaan batu topaz. Batu topaz termasuk deretan batu mulia yang mempunyai nilai kekerasan setingkat di bawah intan, kandungan unsur batu topaz terdiri dari gugusan silikon yang mengandung unsur alumunium, fluorine dan hidroxil dengan rumus kimia $\mathrm{AL}_{2} \mathrm{SiO}_{4}\left(\mathrm{OH}_{4} \mathrm{~F}\right)_{2}{ }^{[1]}$ dapat menimbulkan reaktivitas sebesar $0,0741 \%^{[2]}$ untuk massa batu topaz sebesar $1,5 \mathrm{~kg}$. Besarnya reaktivitas tersebut akan menimbulkan efek ketidaksetimbangan reaktivitas di dalam teras reaktor dan perubahan reaktivitas akan merubah daya. Bila reaktor beroperasi pada kondisi otomatis, perubahan daya reaktor akan dipantau oleh sistem kanal pengatur daya (JKT04 DX001). Sistem kanal pengatur daya dilengkapi dengan sistem kendali kalang tertutup yang terhubung dengan batang kendali pengatur (reg-rod) yang berfungsi untuk mempertahankan daya pada tingkat daya tertentu. Perubahan daya reaktor yang terlalu cepat/ekstrim melebihi kecepatan batang kendali pengatur (reg-rod) dalam mengkonpensasi laju perubahan reaktivitas akan memicu sistem proteksi reaktor (SPR) untuk melakukan pemadaman reaktor secara otomatis.

Untuk memenuhi kebutuhan pihak pengguna dalam melayani iradiasi target batu topaz, maka pemasukan dan pengambilan target topaz dapat dilakukan saat reaktor beroperasi. Ada dua jenis batu topaz; pertama "London Blue" waktu iradiasi 10 jam, ke dua "Swiss Blue" waktu iradiasi 3 jam. Pembatasan waktu menunjukan warna yang dituju, oleh sebab itu penanganan target topaz harus sesuai dengan tujuan yang diharapkan.

Evaluasi penanganan target iradiasi batu topaz pada siklus operasi teras 94 dan 95 reaktor RSG-GAS dimaksudkan untuk menilai bahwa keselamatan penanganan target batu topaz telah terpenuhi . Lingkup yang dievaluasi adalah data penanganan target batu topaz yang ada dalam buku induk operasi dan formulir iradiasi target topaz siklus operasi 94 dan 95. Hasil evaluasi diharapkan dapat memberikan gambaran mengenai penanganan iradiasi target batu topaz saat reaktor operasi dan dapat digunakan sebagai bahan acuan untuk perbaikan kinerja operator reaktor dalam penanganan iradiasi target di reaktor RSG-GAS.

\section{DASAR TEORI}

Pengoperasian reaktor nuklir dapat berlangsung apabila seluruh persyaratan operasi baik persyaratan administrasi maupun persyaratan teknis sudah terpenuhi. Untuk tujuan keselamatan personil yang bekerja di jembatan geser kolam reaktor (misalnya pada penanganan Iradiasi), maka sistem purifikasi KBE01, sistem FAK01 dan sistem KBE02 dengan pemanas (heater) dioperasikan. Fungsi sistem purifikasi adalah untuk menjaga konduktivitas air pendingin kolam pada rentang nilai BKO sebesar $(\leq 8 \mu \mathrm{S} / \mathrm{cm})$ dan dengan Warm Water Layer (WWL) dapat mengurangi laju dosis Gamma di permukaan kolam 
reaktor tidak melebihi $10 \mathrm{mrem} / \mathrm{jam}{ }^{[3,4]}$. Kelancaran operasi reaktor tergantung pada kinerja sistem operasi, sistem keselamatan, dan keandalan dari struktur, sistem dan komponen (SSK) reaktor serta faktor manuasi dalam kegiatan iradiasi target. Berdasarkan pada analisis iradiasi topaz di empat posisi IP RSG-GAS No.ldent : RSG.OR.01.10.44.11 pemasukan dan pengeluaran target topaz dapat dilakukan saat reaktor beroperasi[5,6].

Pengendalian operasi reaktor RSG-GAS dilakukan oleh 8 buah batang kendali yang terletak pada posisi E-9, G6, F-8, F5, C-5, C-8, D-6 dan B-7 di teras reaktor. Batang kendali pada posisi $\mathrm{C}-8$ dipilih sebagai batang kendali pengatur (reg-rod) sedangkan sisanya berfungsi sebagai batang kendali kompensasi (bank). Batang kendali terbuat dari logam paduan AgInCd (80\%, 15\%, 5\%) berbentuk garpu yang dapat bergerak keluar-masuk sepanjang $600 \mathrm{~mm}$ pada sebuah bahan bakar kendali. Fungsi dari sistem kendali adalah untuk menghidupkan dan mematikan reaktor, menjamin subkritikalitas dan mempertahankan daya pada tingkat tertentu secara otomatis. Daerah operasi efektif batang kendali adalah dari ketinggian $250 \mathrm{~mm}$ pada awal siklus sampai ketinggian $550 \mathrm{~mm}$ pada akhir siklus operasi, dengan kondisi "bank" (rata). Bila posisinya telah berbeda sekitar $10 \mathrm{~mm}$ terhadap batang kendali lain, maka operator akan menaikan/menurunkan batang kendali bank satu per satu sehingga tercapai posisi rata kembali untuk seluruh posisi batang kendali. Penempatan posisi batang kendali di teras reaktor telah diperhitungkan agar kerataan fluks neutron di teras tercapai[7]. Pada Gambar 1: Menunjukan Konfigurasi Teras Kerja 94 Reaktor RSG-GAS, konfigurasi ini terdapat posisi Irradiation Position (IP) dan 8 posisi batang kendali;

\begin{tabular}{|c|c|c|c|c|c|c|c|c|c|}
\hline f 02 & F & (1) & 514 & RS & RS 2 & RS 3 & RS 4 & RS 5 & F 0 \\
\hline$F=5$ & $52+84$ & Fit & $37+73$ & 432 & $F 34$ & $J=36$ & 153 & $F 1$ & $56+7{ }^{2}$ \\
\hline $60+83$ & $\mathrm{~F}=04$ & F 19 & 740 & $\begin{array}{c}\text { FE RI } \\
593\end{array}$ & $\begin{array}{c}\text { FE RI } \\
579\end{array}$ & $\begin{array}{c}\text { FE RI } \\
570\end{array}$ & $\begin{array}{c}\text { FE RI } \\
592\end{array}$ & $F 06$ & $\mathrm{~F} 03$ \\
\hline 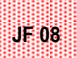 & $1 / 24$ & $\begin{array}{c}\text { FE RI } \\
589\end{array}$ & $\begin{array}{c}\text { FE RI } \\
557\end{array}$ & $\begin{array}{c}\text { FE RI } \\
555\end{array}$ & 再 & \begin{tabular}{|l|} 
JDA07+13 \\
RI - 564 \\
\end{tabular} & $\begin{array}{c}\text { FE RI } \\
578\end{array}$ & $\begin{array}{c}\text { FE RI } \\
572\end{array}$ & $\begin{array}{c}\text { FE RI } \\
582\end{array}$ \\
\hline$F \quad 13$ & $\mathrm{~F}^{\mathrm{D}} \mathrm{23}$ & $\begin{array}{c}\text { FE RI } \\
568\end{array}$ & $\begin{array}{c}\text { FE RI } \\
556\end{array}$ & \begin{tabular}{|l|} 
JDA04+12 \\
$R I-585$ \\
\end{tabular} & $\begin{array}{c}\text { FE RI } \\
559\end{array}$ & $\begin{array}{c}\text { FE RI } \\
573\end{array}$ & \begin{tabular}{|l|} 
JDA05+11 \\
RI - 583
\end{tabular} & $\begin{array}{c}\text { FE RI } \\
549\end{array}$ & $\begin{array}{c}\text { FE RI } \\
576\end{array}$ \\
\hline$f 20$ & F 21 & $\begin{array}{c}\text { FE RI } \\
571\end{array}$ & \begin{tabular}{|l|} 
JDA02+16 \\
RI - 562 \\
\end{tabular} & $\begin{array}{c}\text { FE RI } \\
550\end{array}$ & ${ }^{\infty}$ & 106 & $\begin{array}{c}\text { FE RI } \\
565\end{array}$ & $p_{104}$ & $\begin{array}{c}\text { FE RI } \\
567\end{array}$ \\
\hline \multicolumn{2}{|c|}{$P R T F$} & $\begin{array}{c}\text { FE RI } \\
569\end{array}$ & ${ }^{\infty 01}$ & $\begin{array}{c}\text { FE RI } \\
560\end{array}$ & ${ }^{07}$ & ${ }^{0}$ & $\begin{array}{c}\text { FE RI } \\
552\end{array}$ & \begin{tabular}{|l|} 
JDA08+09 \\
RI - 561 \\
\end{tabular} & $\begin{array}{c}\text { FE RI } \\
574\end{array}$ \\
\hline 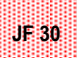 & 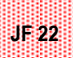 & $\begin{array}{c}\text { FE RI } \\
586\end{array}$ & $\begin{array}{c}\text { FE RI } \\
551\end{array}$ & \begin{tabular}{|l|} 
JDA03+14 \\
RI - 584 \\
\end{tabular} & $\begin{array}{c}\text { FE RI } \\
575\end{array}$ & $\begin{array}{c}\text { FE RI } \\
548\end{array}$ & \begin{tabular}{|l} 
JDA06+15 \\
RI - 591
\end{tabular} & $\begin{array}{c}\text { FE RI } \\
547\end{array}$ & $\begin{array}{c}\text { FE RI } \\
554\end{array}$ \\
\hline${ }^{1}{ }^{29}$ & ${ }^{2}{ }^{2}$ & $\begin{array}{c}\text { FE RI } \\
594\end{array}$ & $\begin{array}{c}\text { FE RI } \\
580\end{array}$ & $\begin{array}{c}\text { FE RI } \\
581\end{array}$ & \begin{tabular}{|l} 
JDA01+10 \\
RI - 563
\end{tabular} & क्ष & $\begin{array}{c}\text { FE RI } \\
553\end{array}$ & $\begin{array}{c}\text { FE RI } \\
558\end{array}$ & $\begin{array}{c}\text { FE RI } \\
590\end{array}$ \\
\hline 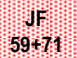 & 1728 & $\mathrm{~F} 26$ & 16 & $\begin{array}{c}\text { FE RI } \\
588\end{array}$ & $\begin{array}{c}\text { FE RI } \\
577\end{array}$ & $\begin{array}{c}\text { FE RI } \\
566\end{array}$ & $\begin{array}{c}\text { FE RI } \\
587\end{array}$ & $54+\mathrm{NS}$ & $F 10$ \\
\hline K & $\mathbf{J}$ & H & G & $\mathbf{F}$ & E & D & C & B & $\mathbf{A}$ \\
\hline
\end{tabular}

Keterangan : 
$\mathrm{B}=$ Beryllium, $\mathrm{BS}+=$ Beryllium dengan sumbat, $\mathrm{Al}=$ Aluminium Stopper tanpa sumbat, $\mathrm{RI}=$ Elemen Bakar, NS = Sumber Neutron

Gambar 1: Konfigurasi Teras Kerja 94 Reaktor RSG-GAS

Karakteristik batang kendali dan keseimbangan reaktivitas teras kerja 94 reaktor RSG-GAS disajikan dalam Tabel 1.

Tabel 1. Neraca Reaktivitas Teras 94

\begin{tabular}{|c|l|c|c|}
\hline \multirow{2}{*}{ No } & \multicolumn{1}{|c|}{ Reaktivitas } & \multicolumn{2}{c|}{ Nilai batang Kendali } \\
\cline { 3 - 4 } & & $\$$ & $\%$ \\
\hline 1. & Reaktivitas Total Batang Kendali & 17,008 & 13,0107 \\
\hline 2. & Reaktivitas Padam & 7,8750 & 6,0245 \\
\hline 3. & Reaktivitas Lebih Teras 94 & 9,1325 & 6,9864 \\
\hline 4. & Reaktivitas pada kondisi Stuck Rod & 5,4100 & 4,1388 \\
\hline 5. & $\begin{array}{l}\text { Reaktivitas Batang Kendali Terbesar } \\
\text { JDA07 + 13 posisi teras D-4 }\end{array}$ & 2,4650 & 1,8857 \\
\hline
\end{tabular}

Sumber : hasil kalibrasi batang kendali laporan operasi teras 94

Karakteristik batang kendali dan keseimbangan reaktivitas teras kerja 95 reaktor RSG-GAS disajikan dalam Tabel 2.

Tabel 2. Neraca Reaktivitas Teras 95

\begin{tabular}{|l|l|c|c|}
\hline \multirow{2}{*}{ No } & \multicolumn{1}{|c|}{ Reaktivitas } & \multicolumn{2}{c|}{ Nilai batang Kendali } \\
\cline { 3 - 4 } & & $\$$ & $\%$ \\
\hline 1. & Reaktivitas Total Batang Kendali & 16,885 & 12,9171 \\
\hline 2. & Reaktivitas Padam & 7,6800 & 5,8753 \\
\hline 3. & Reaktivitas Lebih Teras 94 & 9,2050 & 7,0418 \\
\hline 4. & Reaktivitas pada kondisi Stuck Rod & 5,2425 & 4,0106 \\
\hline 5. & $\begin{array}{l}\text { Reaktivitas Batang Kendali Terbesar } \\
\text { JDA07 + 13 posisi teras D-4 }\end{array}$ & 2,4375 & 1,8647 \\
\hline
\end{tabular}

Sumber : hasil kalibrasi batang kendali laporan operasi teras 95

catatan: Reaktivitas Stuck Rod = Reaktivitas padam - Reaktivitas erbesar

Reaktivitas Lebih = Reaktivitas Total BK - Reaktivitas padam

Karakteristik batang kendali pengatur (reg-rod) reaktor RSG-GAS seperti tersaji pada Tabel 3. berikut ini;

Tabel 3. Karakteristik batang kendali pengatur reaktor RSG-GAS

\begin{tabular}{|l|lll|c|}
\hline No & \multicolumn{3}{|c|}{ Parameter } & Nilai \\
\hline 1. & $\begin{array}{l}\text { Reaktivitas batang kendali pengatur ( } \rho r) \\
\text { Teras 94 }\end{array}$ & $1,8857 \%$ \\
\hline 2. & $\begin{array}{l}\text { Reaktivitas batang kendali pengatur ( } \rho r) \\
\text { Teras 95 }\end{array}$ & $1,8647 \%$ \\
\hline
\end{tabular}




\begin{tabular}{|l|l|l|}
\hline 3. & Panjang langkah $(H r)$ & $600 \mathrm{~mm}$ \\
\hline 4. & Kecepatan $(\mathrm{Vr})$ & $0,538 \mathrm{~mm} / \mathrm{s}$ \\
\hline 5. & Laju reaktivitas rerata & $2,06 \times 10^{-3} \% / \mathrm{s}$ \\
\hline
\end{tabular}

Sumber : LAK reaktor rsg-gas revisi.10.1 thn 2011

Untuk memperkirakan sisipan reaktivitas maksimum akibat yang ditimbulkan oleh pemasukan dan pengambilan target iradiasi batu topaz dapat digunakan rumus berikut:

$\left(\frac{d \rho}{d t}\right)_{\text {maks }}=\frac{\rho r}{H r} V r=\% s^{-}$

Untuk menghidari perubahan daya reaktor terlalu ekstrim akibat dari pemasukan dan pengambilan target, maka operator dimeja kendali RKU harus memperhatikan sistem kanal pemantau daya (JKT04 DX001) dan display digital daya reaktor, begitu juga dengan operator pelaksana iradiasi target di kolam reaktor dapat melihat display digital daya di dinding lantai $13,00 \mathrm{~m}$. Operator dapat melakukan penanganan dengan gerakan pelan dan terputusputus, sehingga reaktivitas yang diberikan ke teras reaktor lebih kecil atau sama dengan kemampuan batang kendali pengatur (reg-rod) [8,9], seperti besaran yang ditunjukan dengan rumus:

$\left(\frac{d \rho}{d t}\right)_{\text {target }} \leq\left(\frac{d \rho}{d t}\right)_{\text {reg rod }}$

Pemantauan daya reaktor secara otomatis dilakukan oleh kanal pemantau daya (JKT04 DX001) terhubung langsung dengan batang kendali pengatur (reg-rod) dan berfungsi untuk mempertahankan kesetabilan daya pada rentang nilai batasan dan kondisi operasi (BKO). Perubahan daya reaktor yang terlalu cepat/ekstrim akan membuat batang kendali pengatur (reg-rod) tidak mampu untuk mengkompensasinya dan memicu sistem proteksi reaktor (SPR) untuk melakukan pemadaman reaktor secara otomatis.

\section{TATA KERJA}

Metode dan lingkup yang dilakukan dengan tahap:

1. Mengumpulkan data tentang persyaratan operasi reaktor yaitu Instruksi Operasi (IO) dan Formulir Iradiasi Target yang sudah mempunyai LAK. Data yang dikumpulkan ini adalah data persyaratan teknis maupun administrasi yang harus terpenuhi sebelum reaktor beroperasi.

2. Buku Induk Operasi Reaktor dan Formulir Iradiasi Target pada siklus operasi 94 dan siklus operasi 95.

3. Melakukan identifikasi dan sortir data terkait jumlah target topaz dan perubahan ketinggian batang kendali (daya)

4. Setelah diperoleh data tersebut, kemudian dilakukan evaluasi dan pembahasan sehingga guna untuk memperoleh kesimpulan. Data hasil evaluasi disajikan dalam bentuk Tabel.

\section{HASIL DAN PEMBAHASAN}

Hasil identifikasi iradiasi target batu topaz "London Blue" dengan waktu iradiasi selama 10 jam pada siklus operasi 94 disajikan pada Tabel $3^{[10]}$, dibawah ini; 
Tabel. 3. Hasil Pelaksanaan Iradiasi Target Batu Topaz Periode Siklus Operasi Teras 94

\begin{tabular}{|l|l|l|c|c|c|c|}
\hline No. & No.Target & $\begin{array}{c}\text { Lama } \\
\text { Iradiasi }\end{array}$ & $\begin{array}{c}\text { Jumlah } \\
\text { pengantian }\end{array}$ & $\begin{array}{c}\text { Jumlah } \\
\text { Kapsul/ } \\
\text { Posisi }\end{array}$ & $\begin{array}{c}\text { Massa } \\
(\mathrm{kg})\end{array}$ & $\begin{array}{c}\text { Total Iradiasi } \\
\text { Topaz } \\
(\mathrm{kg})\end{array}$ \\
\hline 1. & $10 / \mathrm{Po} / 2017$ & $10 \mathrm{Jam}$ & 6 & 4 & 1,5 & 36 \\
\hline 2. & $11 / \mathrm{T} / \mathrm{Po} / 2017$ & $10 \mathrm{Jam}$ & 6 & 4 & 1,5 & 36 \\
\hline 3. & $12 / \mathrm{T} / \mathrm{Po} / 2017$ & $10 \mathrm{Jam}$ & 6 & 4 & 1,5 & 36 \\
\hline 4. & $13 / \mathrm{T} / \mathrm{Po} / 2017$ & $10 \mathrm{Jam}$ & 6 & 4 & 1,5 & 36 \\
\hline 5. & $14 / \mathrm{T} / \mathrm{Po} / 2017$ & $10 \mathrm{Jam}$ & 6 & 4 & 1,5 & 36 \\
\hline 6. & $15 / \mathrm{T} / \mathrm{Po} / 2017$ & $10 \mathrm{Jam}$ & 6 & 4 & 1,5 & 36 \\
\hline 7. & $16 / \mathrm{T} / \mathrm{Po} / 17$ & $10 \mathrm{Jam}$ & 6 & 4 & 1,5 & 36 \\
\hline 8. & $17 / \mathrm{T} / \mathrm{Po} / 17$ & $10 \mathrm{Jam}$ & 6 & 4 & 1,5 & 36 \\
\hline 9. & $18 / \mathrm{T} / \mathrm{Po} / 17$ & $10 \mathrm{Jam}$ & 6 & 4 & 1,5 & 36 \\
\hline \multicolumn{7}{|c|}{ TOTAL BERAT/JUMLAH BATU TOPAZ TERIRADIASI } \\
\hline
\end{tabular}

Ket; IO NO: 94/01/2017 - 94/09/2017

Jadi untuk satu teras kerja (siklus) 94

telah diiradiasi batu topaz sejumlah = $324 \mathrm{~kg}$.

Dari jumlah total pelaksanaan iradiasi target batu topaz pada operasi teras kerja 94 adalah $6 \times 4 \times 9=216$ kali
Hasil evaluasi iradiasi target batu topaz "London Blue" waktu iradiasi selama 10 jam dan "Swiss Blue" waktu iradiasi selama 3 jam pada siklus operasi 95 disajikan pada Tabel 4 dibawah ini;

Tabel. 4. Hasil Pelaksanaan Iradiasi Target Batu Topaz Periode Siklus Operasi Teras 95

\begin{tabular}{|l|c|c|c|c|c|c|}
\hline No. & No.Target & $\begin{array}{c}\text { Lama } \\
\text { Iradiasi }\end{array}$ & $\begin{array}{c}\text { Jumlah } \\
\text { pengantian }\end{array}$ & $\begin{array}{c}\text { Jumlah } \\
\text { Kapsul/ } \\
\text { Posisi }\end{array}$ & $\begin{array}{c}\text { Massa } \\
(\mathrm{kg})\end{array}$ & $\begin{array}{c}\text { Total Iradiasi } \\
\text { Topaz } \\
(\mathrm{kg})\end{array}$ \\
\hline 1. & $01 / \mathrm{Po} / 2018$ & $10 \mathrm{Jam}$ & 6 & 4 & 1,5 & 36 \\
\hline 2. & $02 / \mathrm{Po} / 2018$ & $3 \mathrm{Jam}$ & 10 & 4 & 1,5 & 60 \\
\hline 3. & $04 / \mathrm{Po} / 2018$ & $10 \mathrm{Jam}$ & 6 & 4 & 1,5 & 36 \\
\hline 4. & $05 / \mathrm{Po} / 2018$ & $3 \mathrm{Jam}$ & 10 & 4 & 1,5 & 60 \\
\hline 5. & $06 / \mathrm{Po} / 2018$ & $10 \mathrm{Jam}$ & 6 & 4 & 1,5 & 36 \\
\hline 6. & $05 / \mathrm{Po} / 2018$ & $3 \mathrm{Jam}$ & 10 & 4 & 1,5 & 60 \\
\hline 7. & $07 / \mathrm{Po} / 2018$ & $10 \mathrm{Jam}$ & 6 & 4 & 1,5 & 36 \\
\hline 8. & $08 / \mathrm{Po} / 2018$ & $3 \mathrm{Jam}$ & 10 & 4 & 1,5 & 60 \\
\hline 9. & $09 / \mathrm{Po} / 2018$ & $10 \mathrm{Jam}$ & 6 & 4 & 1,5 & 36 \\
\hline 10 & $10 / \mathrm{Po} / 2018$ & $3 \mathrm{Jam}$ & 10 & 4 & 1,5 & 60 \\
\hline 11. & $11 / \mathrm{Po} / 2018$ & 10 Jam & 6 & 4 & 1,5 & 36 \\
\hline 12 & $12 / \mathrm{Po} / 2018$ & $3 \mathrm{Jam}$ & 10 & 4 & 1,5 & 60 \\
\hline 13. & $13 / \mathrm{Po} / 2018$ & 10 Jam & 6 & 4 & 1,5 & 36 \\
\hline 14. & 14/Po/2018 & 3 Jam & 10 & 4 & 1,5 & 60 \\
\hline
\end{tabular}




\begin{tabular}{|l|l|c|c|c|c|c|}
\hline 15. & $15 / \mathrm{Po} / 2018$ & $10 \mathrm{Jam}$ & 6 & 4 & 1,5 & 36 \\
\hline 16. & $16 / \mathrm{Po} / 2018$ & $3 \mathrm{Jam}$ & 10 & 4 & 1,5 & 60 \\
\hline 17. & $17 / \mathrm{Po} / 2018$ & $10 \mathrm{Jam}$ & 6 & 4 & 1,5 & 36 \\
\hline 18. & $18 / \mathrm{Po} / 2018$ & $3 \mathrm{Jam}$ & 10 & 4 & 1,5 & 60 \\
\hline \multicolumn{7}{|c|}{ TOTAL BERAT/JUMLAH BATU TOPAZ TERIRADIASI } \\
\hline
\end{tabular}

Ket; IO NO: 95/01/2018 - 95/09/2018

Dari data Tabel 2 di atas jumlah/berat batu topaz yang sudah dihasilkan adalah sebagai berikut;

1. Batu topaz durasi (Swiss Blue) iradiasi 3 jam ;

Dari jumlah total pelaksanaan iradiasi target batu topaz (Swiss Blue) pada operasi teras kerja 95 adalah $9 \times 4 \times$ $10=360$ kali

2. Batu topaz (London Blue) durasi iradiasi 10 jam ;

Dari jumlah total pelaksanaan iradiasi target batu topaz (London Blue) pada operasi teras kerja 95 adalah $9 \times 4 \times$ $6=216$ kali

Jadi jumlah total untuk teras kerja (siklus) 95 adalah 360 kali +216 kali $=576$ kali, dengan jumlah total $864 \mathrm{~kg}$

Pengendalian operasi reaktor pada moda operasi daya konstan 15 MW, sebagaimana kondisi yang disajikan pada Tabel 1. Neraca Reaktivitas Teras 94. Dimana harga reaktivitas batang kendali total adalah $13,548 \%$ dengan reaktivitas lebih teras $6,9462 \%$, secara umum nampak keseimbangan reaktivitas teras dan telah memenuhi persyaratan untuk melaksanakan operasi satu siklus untuk tujuan iradiasi target. Bila pemasukan dan pengambilan target topaz dilakukan saat reaktor operasi otomatis, maka akan terjadi perubahan reaktivitas sebesar reaktivitas target topaz dan akan dikompensasi oleh batang kendali pengatur, sehingga posisi batang kendali pengatur akan bergerak mengikuti perubahan tersebut. Selisih batang kendali pengatur (reg-rod) sebelum dan sesudah target dimasukan sama dengan harga reaktivitas target. Diketahui reaktivitas target topaz sebesar $0,0741 \%$, reaktivitas tersebut akan dikompensasi oleh batang kendali pengatur (reg-rod) (lihat Tabel 3), sehingga perubahan posisi batang kendali pengatur akan terjadi sebesar:

Perubahan posisi batang kendali pengatur (reg-rod) Teras 94 :

$=\frac{0,074196}{1,885796} \times 600 \mathrm{~mm}=23,5774 \mathrm{~mm}$

Perubahan posisi batang kendali pengatur (reg-rod) Teras 95:

$=\frac{0,074196}{1,864796} \times 600 \mathrm{~mm}=23,8429 \mathrm{~mm}$

Maka akan terjadi selisih ketinggian posisi batang kendali pengatur (reg-rod) sebesar $\pm 23 \mathrm{~mm}$ dengan posisi batang kendali kompensasi (bank). Bila posisinya telah berbeda sekitar $10 \mathrm{~mm}$ terhadap batang kendali kompensasi (bank), maka operator akan menaikan/menurunkan batang kendali kompensasi (bank) satu per satu sehingga tercapai posisi rata kembali untuk seluruh posisi batang kendali. Untuk keselamatan operasi reaktor reaktivitas yang diberikan ke teras reaktor harus lebih kecil atau sama dengan kemampuan batang kendali pengatur (reg-rod), sebagaimana yang telah dinyatakan pada persamaan 2 .

Penanganan target topaz pada fasilitas di iradiasi IP terdiri dari posisi D- 
9, E-4, G-7, B-6, dengan metode pelaksanaan berpasangan seperti selama ini yang dilakukan oleh Supervisor/Operator reaktor, seperti posisi D-9 berpasangan dengan Posisi E4 dan posisi G-7 berpasangan dengan B6, posisi berpasangan yang dimaksud adalah posisi penanganan target yang berlawanan arah, sehingga terjadi saling meniadakan perubahan reaktivitas di teras reaktor, artinya kalau operator di kolam reaktor kompak dalam penanganannya maka akan terlihat pada display daya digital tidak ada perubahan daya atau stabil pada kisaran $\pm 15 \mathrm{MW}$. Karena penanganan iradiasi target topaz adalah pemasukan dan pengambilan topaz dari dan ke posisi iradiasi, maka untuk satu posisi iradiasi akan terjadi dua kali penanganan yaitu masuk dan keluar (In and Out). Dengan demikian ada dua posisi yang tidak berpasangan saat penanganannya yaitu posisi D-9 topaz keluar dan posisi B-6 topaz masuk. Jika pada posisi D-9 target topaz dikeluarkan, artinya kita memberikan rektivitas negatif terhadap teras, maka pada display daya digital terlihat daya turun, sehingga batang kendali pengatur (reg-rod) merespon naik untuk mengkompensasi perubahan reaktivitas tersebut. Demikian juga sebaliknya yang terjadi pada posisi B-6, saat topaz dimasukan sama dengan memberikan reaktivitas positif ke teras, maka pada display daya digital terlihat daya naik, sehingga batang kendali pengatur (reg-rod) merespon turun untuk mengkompensasi perubahan reaktivitas dalam teras reaktor. Kedua posisi (D-9 dan B-6) sangat memerlukan konsentrasi operator di RKU dengan bantuan display (JKT04 DX001) dan display digital lantai 13 meter. Dengan tetap mempertahankan daya reaktor pada tingkat bawah 14, $3 \mathrm{MW}$ dan tingkat atas $16 \mathrm{MW}$ maka operasi reaktor akan "OK". Ke depan pengalaman lapangan ini akan menjadi usulan untuk dituangkan ke dalam SOP yang baru. Disamping itu dari penelitian yang sudah ada batu topaz seberat $1,5 \mathrm{~kg}$ dapat memberikan reaktivitas positif sebesar 0,0741\% terhadap reaktivitas teras. Batasan dalam LAK RSG-GAS Revisi 10.1 reaktivitas maksimum pada satu posisi iradiasi untuk target bergerak $<0,5 \%$, sehingga reaktor dalam kondisi aman.

Pengoperasian reaktor pada siklus tersebut telah memenuhi semua persyaratan yang diwajibkan, termasuk persyaratan-persyaratan yang harus dipenuhi sebelum iradiasi target dimasukan pada posisi iradiasi di teras reaktor seperti; formulir iradiasi telah terisi, tersedia LAK target. Ada 2 prosedur terkait yang digunakan, yaitu :Petunjuk Pelaksanaan Pengukuran Reaktivitas Target Topaz di Teras Reaktor. No.Ident : RSG.OR.20.03.10. Rev: 00, dan Petunjuk Pelaksanaan Penanganan Iradiasi Batu Topaz Posisi IP (Iradiation Position) di RSG-GAS No. Ident: RSG,OR.08.03.41.10. Rev: 00. Kedua prosedur tersebut perlu direvisi karena masih dalam bentuk (format) Juknis seharusnya sudah dalam bentuk SOP, revisi sangat diperlukan manakala faktor keselamatan dalam pelaksanaan belum terakomodir secara spesifik, seperti yang tertulis dalam Juknis; Pada Langkah ke. 5.1.a. Iradiasi Batu Topaz pada poin f) Supervisor atau Operator reaktor akan memasukan kapsul topaz pada posisi iradiasi sesuai permohonan iradiasi. Pada poin g) Pastikan bahwa semua pemasukan batu topaz telah sesuai dengan petunjuk pelaksanaan. Jadi jelas dalam Juknis tidak ada tertulis saat pemasukan dan pengambilan target topaz dilakukan dengan cara pelan-pelan dan gerakan terputus-putus sambil melihat perubahan daya pada display daya digital. Ke depan saat Juknis direvisi menjadi SOP maka point tersebut harus masuk dalam SOP, karena terkait dengan keselamatan operasi reaktor. 
Keselamatan

dalam

pengoperasian reaktor hanya dapat dicapai apabila persyaratan administrasi maupun teknis sudah terpenuhi sebelum reaktor dioperasikan. Tujuan keselamatan dalam pengoperasian reaktor adalah untuk melindungi personil, instalasi dan lingkungan dari bahaya radiasi akibat proses reaksi fisi yang terjadi dalam teras reaktor. Untuk mengurangi resiko tersebut maka sistem bantu keselamatan seperti sistem purifikasi air kolam reaktor KBE01, sistem FAK01 dan KBE02 dengan pemanas (heater) sudah dioperasikan, dengan demikian Warm Water Layer (WWL) sudah terbentuk dipermukaan air kolam reaktor setebal $1,5 \mathrm{~m}$ dengan indikator beda suhu (JAA01 CT003) sebesar $\geq 8{ }^{\circ} \mathrm{C}$. Fungsi sistem purifikasi adalah untuk menjaga konduktivitas air pendingin kolam pada rentang nilai BKO sebesar $(\leq 8 \mu \mathrm{S} / \mathrm{cm})$ dan dengan Warm Water Layer (WWL) dapat mengurangi laju dosis Gamma di permukaan kolam reaktor tidak melebihi $10 \mathrm{mrem} / \mathrm{jam}^{[4,7]}$. Sehingga personil dalam melaksanakan kegiatan pemasukan dan penarikan iradiasi target topaz terlindungi dari paparan radiasi dan nyaman dalam melaksanakan kegiatan.

\section{KESIMPULAN}

Data hasil evaluasi penanganan target iradiasi batu topaz pada siklus operasi 94 dan 95 dapat disimpulkan bahwa kegiatan iradiasi batu topaz dilakukan sebanyak 216 kali di teras 94 dan 576 kali di teras 95 dengan total berat batu topaz teriradiasi yaitu sebesar $846 \mathrm{~kg}$. Untuk besarnya perubahan tinggi batang kendali pengatur yaitu $23 \mathrm{~mm}$. Dari hasil evaluasi penanganan target iradiasi batu topaz pada siklus 94 dan 95 reaktor RSG-GAS didapatkan bahwa kegiatan tersebut dilakukan dengan aman dan selamat

\section{SARAN}

1. Display daya digital reaktor inputnya diambil dari detektor rapat fluks neutron terkoreksi $\mathrm{N}^{16}$ pada jangkauan daya, pengukurannya terlalu sensitif, sehingga range perubahan daya yang tampil dimonitor \pm lebih besar bila dibandingkan dengan daya sesungguhnya yang terukur pada kanal pengatur daya (JKT04 DX001) yang disetting berdasarkan kalibrasi daya reaktor secara kalori metri. Kedepan diharapkan input untuk display daya digital diambil dari kanal pengatur daya (JKT04 DX001).

2. Petunjuk pelaksanaan penanganan iradiasi batu topaz posisi IP disarankan bisa dirubah menjadi Standar Operasional Prosedur (SOP)

3. SOP tersebut selanjutnya bisa diberikan kepada Subbidang terkait untuk menunjang kegiatan tersebut.

\section{DAFTAR PUSTAKA}

11] PRSG-BATAN. "Laporan Kajian Iradiasi Batuan Topaz Di RSG-GAS No.Ident: 003/RN 00 03/RSG 2.1". Jakarta Th 2014.

[2] Sutrisno, "Perhitungan Reaktivitas Batu Topaz 1,5 kg Posisi D-9 Dengan Program BATAN 2-DIFF" Prosiding Seminar Teknologi dan Aplikasi Reaktor Nuklir. Jakarta Th 2012.

[3] Pardi, "Evaluasi Kinerja Sistem Purifikasi Dan Lapisan Air Hangat (KBE02) Reaktor RSG-GAS" Prosiding Seminar Teknologi dan Aplikasi Reaktor Nuklir. Jakatra Th 2016.

[4] Pardi, Purwadi, "Evaluasi Kejadian Abnormal/Gangguan Operasi Reaktor RSG-GAS Kurun Waktu Th 2015 - 2017" REAKTOR Buletin 
Pengelolaan Reaktor Nuklir Volume XV, No.2 Oktober Th 2017.

[5] PRSG-BATAN, "Analisis Iradiasi Topaz di Empat Posisi IP RSG-GAS No.Ident: RSG.OR.01.10.44.11". Jakarta Th 2011.

[6] PRSG-BATAN, "Petunjuk Pelaksanaan Penanganan Iradiasi Batu Topaz Posisi IP (Irradiation Position) di RSG-GAS No.ldent : RSG.OR.08.03.41.10 rev.00" Jakarta Th.2011.

[7] Iman Kuntoro, "Peningkatan Kecepatan Batang Kendali Pengatur Reaktor RSG-GAS" TRI DASA
MEGA Jurnal Teknologi Reaktor Nuklir Volume 2 Nomor 1, Februari. Jakarta Th 2000

[8] Kusno, "Penanganan Target Ketika Reaktor Beroperasi" Diktat PUSDIKLAT- BATAN. Jakarta Th 2001

[9] PRSG-BATAN, "Laporan Analisis Keselamatan Reaktor RSG-GAS Revisi 10.1". Jakarta Th 2011

[10] PRSG-BATAN, "Buku Induk Operasi Reaktor RSG-GAS No. 335 - 350" Jakarta Th 2017 - 2018. 